\title{
The temperature sensitivity of Bacillus subtilis DB1005 is due to insufficient activity, rather than insufficient concentration, of the mutant $\sigma^{\text {A factor }}$
}

\author{
Ban-Yang Chang, Chao-Tsai Liao, Yu-Der Wen and Wen-Horng Wang
}

Author for correspondence: Ban-Yang Chang. Tel: +886 4287 4754. Fax: +886 42861905. e-mail: bychang@mail.nchu.edu.tw

Agricultural Biotechnology Laboratories, National Chung Hsing University, Taichung, Taiwan 40227 Republic of China

\begin{abstract}
The $\sigma^{A}$ factor of Bacillus subtilis DB1005 contains two amino acid substitutions (I198A and 1202A) in the promoter -10 binding region. It has been confirmed that this $\sigma$ factor is responsible for the temperature sensitivity of $B$. subtilis DB1005. An investigation was conducted into how the mutant $\sigma^{A}$ could cause temperature-sensitive (Ts) cell growth by analysing its structural stability, cellular concentration and transcriptional activity. The mutant $\sigma^{A}$ was unstable even at the permissive temperature of $37^{\circ} \mathrm{C}\left(t_{1 / 2} 59 \mathrm{~min}\right)$, whereas the wildtype counterpart was fairly stable under the same conditions $\left(t_{1 / 2}>600 \mathrm{~min}\right)$. However, neither wild-type $\sigma^{A}$ nor mutant $\sigma^{A}$ was stable at $49^{\circ} \mathrm{C}\left(t_{1 / 2} 34 \mathrm{~min}\right.$ and $23 \mathrm{~min}$, respectively). Analyses of the rates of $\sigma^{A}$ synthesis revealed that $B$. subtilis DB1005 was able to compensate for unstable $\sigma^{A}$ by elevating the level of $\sigma^{A}$ at $37^{\circ} \mathrm{C}$ but not at $49^{\circ} \mathrm{C}$. Moreover, overexpression of the mutant $\sigma^{A}$ at $49{ }^{\circ} \mathrm{C}$ could not suppress the Ts phenotype of $B$. subtilis DB1005. This indicates that the temperature sensitivity of $B$. subtilis DB1005 is not due to insufficient $\sigma^{A}$ concentration in the cell. The greater decline of an already reduced activity of the mutant $\sigma^{A}$ at $49{ }^{\circ} \mathrm{C}$ suggests that the temperature sensitivity of $B$. subtilis DB1005 is instead the result of a very low activity of $\sigma^{A}$; probably below a critical level necessary for cell growth.
\end{abstract}

Keywords: Bacillus subtilis, $\sigma^{\mathrm{A}}$ factor, $\alpha$-helix, degradation rate, temperature sensitivity

\section{INTRODUCTION}

$\sigma$ factors direct RNA polymerase to the promoter sites on DNA molecules and initiate the transcription of DNA (Burgess et al., 1969). Sequence alignment of a large number of $\sigma$ factors has revealed four conserved regions in this group of proteins (Helmann \& Chamberlin, 1988; Lonetto et al., 1992). Genetic studies revealed that region 4.2 and region 2.4 are involved in the recognition of promoter DNA (Daniels et al., 1990; Gardella et al., 1989; Kahn \& Ditta, 1991; Siegele et al., 1989; Tatti et al., 1991; Zuber et al., 1989). Region 4.2 at the C-terminus contains a helix-turn-helix motif which is thought to interact specifically with the -35 region of the promoter (Brennan \& Matthews, 1989; Gardella et al., 1989; Siegele et al., 1989). Region 2.4 forms an amphiphilic $\alpha$-helix; certain amino acid

Abbreviation: Ts, temperature-sensitive residues on this helix are believed to participate in sequence-specific contacts with promoter - 10 DNA (Daniels et al., 1990; Siegele et al., 1989; Tatti et al., 1991; Waldburger et al., 1990). Amino acids which confer altered -10 recognition properties are presumably on the hydrophilic face of the amphiphilic $\alpha$-helix in Escherichia coli $\sigma^{70}$ as well as in Bacillus subtilis $\sigma^{\mathrm{A}}, \sigma^{\mathrm{E}}$, $\sigma^{\mathrm{F}}$ and $\sigma^{\mathrm{H}}$ (Daniels et al., 1990; Kenney et al., 1989; Kenney \& Moran, 1991; Siegele et al., 1989; Tatti et al., 1991; Zuber et al., 1989). Thus, amino acids on the hydrophobic face of the promoter -10 binding helix must play different roles.

In order to clarify the roles of the conserved hydrophobic amino acids on the hydrophobic face of the promoter -10 binding helix of $\sigma^{\mathrm{A}}$, we constructed several B. subtilis sigA mutants which contained amino acid substitutions in this region by using site-directed mutagenesis (Chang \& Doi, 1993b). One of the mutants has two amino acid substitutions, I198A and I202A, on the 
(a)

DB2

DB1005

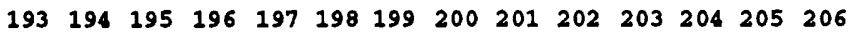
Trp I1e Arg Gin Ala Ile Thr Arg Ala Ile Ala Asp Gin Ala TGGATCAGACAGGCGATTACACGCGCCATTGCCGATCAGGCG TGGATCAGACAGGCGGCTACACGCGCDGCTGCCGATCAGGCG Ala Ala (b)

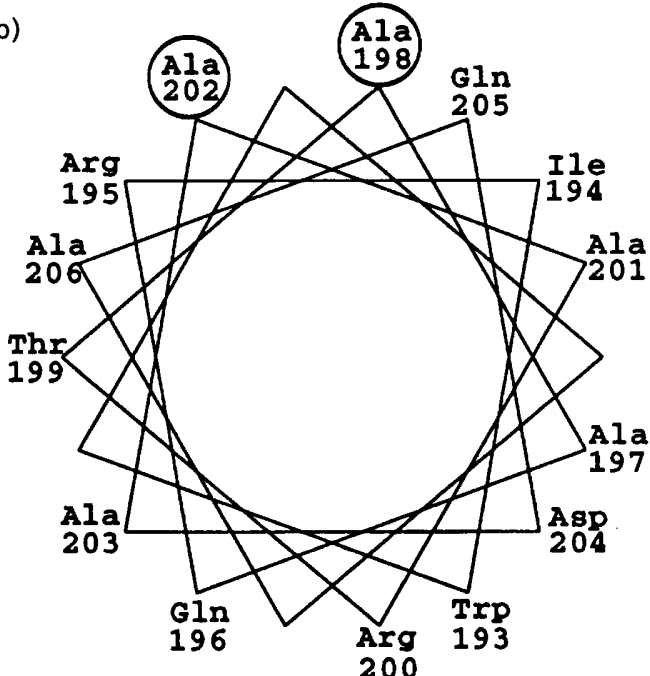

(c)

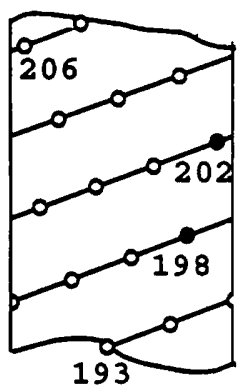

Fig. 1. Amino acid substitutions in the $\alpha$ helix of the promoter -10 binding region of B. subtilis $\sigma^{A}$. (a) The top two lines indicate the number and sequence of amino acids in the promoter -10 binding region of the wild-type $\sigma^{A}$. The bottom two lines indicate the sense strand DNA sequences of the wildtype sigA gene of $B$. subtilis $D B 2$ and the mutant sigA gene of $B$. subtilis DB1005. The two substituted alanine codons in DB1005 sigA gene are boxed. (b) Helical wheel representation of the amphiphilic promoter -10 binding helix of DB1005 $\sigma^{A}$. The substituted alanine residues at positions 198 and 202 are circled. (c) Cylindrical plot of the amphiphilic $\alpha$-helix of the promoter -10 binding region of $\sigma^{\mathrm{A}}$. The substituted alanine residues at positions 198 and 202 are indicated by filled circles. hydrophobic face (Fig. 1) and confers a temperaturesensitive (Ts) phenotype on B. subtilis DB1005. The growth of this mutant stops within $30 \mathrm{~min}$ after the temperature upshift $\left(37\right.$ to $\left.49^{\circ} \mathrm{C}\right)$ and resumes after the downshift $\left(49\right.$ to $\left.37^{\circ} \mathrm{C}\right)$. In addition, it suffers from starvation and oxidative stresses at the restrictive temperature (Chang \& Doi, 1993b; Chang et al., 1994). We are interested in determining the nature of the mutant $\sigma^{\mathrm{A}}$ causing the temperature sensitivity of DB1005.

It has been reported that the promoter -10 binding region is within the most hydrophobic domain of $\sigma^{\mathrm{A}}$ and is resistant to protease attack (Chang \& Doi, 1990). Moreover, free $\sigma^{\mathrm{A}}$ is unable to bind promoter DNA unless it associates with RNA polymerase core enzyme and undergoes a conformational change (Chang \& Doi, 1993a). The unexposed nature of the promoter -10 binding region suggests that the replacement of Ile-198 and Ile-202 with alanines would affect the interdigital interaction between amino acids in these two positions and those in other region(s) of $\sigma^{\mathrm{A}}$ both in free- and coreenzyme-associated states. Thus, the temperature sensitivity of $B$. subtilis DB1005 might be due to a certain change in $\sigma^{\mathrm{A}}$ structure, which in turn leads to degradation or altered function of the mutant $\sigma^{\mathrm{A}}$, or a combination of both factors, at elevated temperatures.

We have analysed some properties of the mutant $\sigma^{\mathrm{A}}$ factor. Our data showed that B. subtilis DB1005 $\sigma^{\mathrm{A}}$ was unstable at both permissive and restrictive temperatures, while the wild-type $\sigma^{\mathrm{A}}$ was unstable only at the elevated temperature. We also showed that a higher mutant $\sigma^{\mathrm{A}}$ concentration was unable to suppress the Ts phenotype, supporting the idea that the temperature sensitivity of $B$. subtilis DB1005 is not caused by insufficient $\sigma^{\mathrm{A}}$ concentration. The marked reduction of DB1005 $\sigma^{\mathrm{A}}$ activity at high temperature and its correlation with the temperature sensitivity of $B$. subtilis DB1005 suggests that it is below a critical level necessary for cell growth under heat stress.

\section{METHODS}

Enzymes and chemicals. Restriction enzymes, ligase and other DNA modification enzymes were purchased from BRL and used according to the recommendations of the manufacturer. Anti- $\sigma^{A}$ and anti-GroEL antibodies were prepared as described previously (Chang \& Doi, 1990; Chang et al., 1994). Protein A-Sepharose CL-4B was purchased from Pharmacia. L$\left[{ }^{35} \mathrm{~S}\right]$ methionine $\left[1200 \mathrm{Ci} \mathrm{mmol}{ }^{-1}\left(44.4 \mathrm{TBq} \mathrm{mmol}^{-1}\right)\right]$ and $[\alpha-$ $\left.{ }^{32} \mathrm{P}\right] \mathrm{dCTP}\left[3000 \mathrm{Ci} \mathrm{mmol}^{-1}\left(111 \mathrm{TBq} \mathrm{mmol}^{-1}\right)\right]$ were obtained from Amersham. Other reagents were products of Merck and Serva.

Bacterial strains. B. subtilis strains DB1005 $[\operatorname{trpC} \operatorname{sig} A(\mathrm{Ts})]$, DB430 (trpC npr apr epr bpf ispI) (He et al., 1991) and DB435 [trpC npr apr epr bpfispI sigA (Ts)] are derivatives of DB2 (B. subtilis $168 \operatorname{trpC})$. To construct $B$. subtilis DB435, chromosomal DNA extracted from DB1005 was transformed into $B$. subtilis DB430. Transformants which had the same Ts phenotype and sigA DNA sequence as those of DB1005 were named DB435.

Construction of plasmids containing wild-type or mutant sigA genes expressible in $B$. subtilis. To construct the $\mathrm{pCX} 2 \mathrm{~F}$ plasmid harbouring the wild-type $\operatorname{sig} A$, an EcoRI DNA fragment containing the P1P2 promoter from $B$. subtilis sig $A$ operon was first cut out from the pUC19-43L plasmid and cloned into the promoter probing vector, pWP18 (Wang \& Doi, 1987) to form the plasmid pCC1. This was then cleaved with $S a l$ I to remove the aprE gene, leaving the vector part of 
the plasmid to self-ligate for the generation of the plasmid pCC2. Afterwards, a BglII DNA fragment containing the wild-type sigA gene (including the ribosome-binding sequence) was excised from the $\sigma^{A}$-overexpressing plasmid, pCD2 (Chang \& Doi, 1990), and cloned into the BamHI site of pCC2 to form pCX2F. This construction allowed the sigA gene on $\mathrm{pCX} 2 \mathrm{~F}$ to be controlled both by the transcriptional signal (P1P2 promoter) of the sigA operon and by the translational signal of the sigA gene (Wang \& Doi, 1986). For some reason, the sig $A$ gene of $B$. subtilis DB1005 was difficult to clone with conventional cloning strategies. To overcome this difficulty, the method of gene conversion (Chak et al., 1982; Iglesias \& Trautner, 1983) was adopted. In this approach, the $\mathrm{pCX} 2 \mathrm{~F}$ plasmid was introduced into $B$. subtilis DB1005 and then transformants with kanamycin $(\mathrm{Km})$ resistant and Ts phenotypes were screened. This type of transformant contained plasmid pCX2F5, in which the wildtype sig $A$ allele has been replaced with the Ts sig $A$ allele of $B$. subtilis DB1005. To obtain a B. subtilis DB1005 strain with a pure population of $\mathrm{pCX} 2 \mathrm{~F} 5$, plasmids in the aforementioned Ts transformants were extracted and reintroduced into $B$. subtilis DB1005. The secondary Ts transformants thus obtained were further streaked and purified; these cells contained the mutant $\operatorname{sig} A$ gene on the plasmid as determined by direct sequencing of the $\operatorname{sig} A$ DNA.

Degradation rate of $\sigma^{A}$ and GroEL proteins. To determine the degradation rate of $\sigma^{A}$ protein in vivo, each $B$. subtilis strain was grown in glucose minimal medium (GMM) (Spizizen, 1958) supplemented with $0.004 \%$ tryptophan at $37^{\circ} \mathrm{C}$ to an $\mathrm{OD}_{550}$ of 0.4 (measured with a Milton Roy Company Spectronic 20D spectrophotometer) and the culture was separated into two portions. One of the aliquots was further incubated at $37^{\circ} \mathrm{C}$; the other was transferred to $49^{\circ} \mathrm{C}$. Nine minutes later, the cultures were pulse-labelled with $\mathrm{L}-\left[{ }^{35} \mathrm{~S}\right]$ methionine $\left(1200 \mathrm{Ci} \mathrm{mmol}{ }^{-1}\right)$ at a concentration of $20 \mu \mathrm{Ci} \mathrm{ml} l^{-1}$ for $5 \mathrm{~min}$ and then chased with nonradioactive methionine at a concentration of $5 \mathrm{mM}$. Sampling of the labelled cultures was started 2 min later. At the designated time points, $0.5 \mathrm{ml}$ of each culture was removed, pelleted by centrifugation at $4{ }^{\circ} \mathrm{C}$ for $10 \mathrm{~min}$ and then incubated at $37^{\circ} \mathrm{C}$ for $10 \mathrm{~min}$ in $40 \mu \mathrm{l}$ lysis buffer $(50 \mathrm{mM}$ glucose, $25 \mathrm{mM}$ Tris/ $\mathrm{HCl} \mathrm{pH} 8 \cdot 0,0 \cdot 1 \mathrm{mg}$ lysozyme $\mathrm{ml}^{-1}, 0 \cdot 2 \mathrm{mM}$ PMSF). Afterwards, $20 \mu$ l detergent solution $(1 \%(\mathrm{w} / \mathrm{v})$ SDS, $1 \%$ (v/v) Triton X-100) was added to each sample to disrupt the cells. The sample was then heated to $90^{\circ} \mathrm{C}$ for $3 \mathrm{~min}$ and insoluble cell debris in the samples was removed by centrifugation. To specifically precipitate $\sigma^{A}$ and GroEL proteins in the supernatant simultaneously, a $50 \mu \mathrm{l}$ aliquot of the sample was diluted with $450 \mu \mathrm{l}$ of incubation buffer $(1 \%$ Triton X-100, $0 \cdot 1 \%$ SDS, $100 \mathrm{mM} \mathrm{NaCl}, 10 \mathrm{mM}$ Tris/HCl $\mathrm{pH} 8.0)$ prior to the addition of $1 \mu \mathrm{l}$ each of anti- $\sigma^{\mathrm{A}}$ and antiGroEL antibodies. The mixture was incubated overnight at $4{ }^{\circ} \mathrm{C}$ with gentle shaking (100 r.p.m.) and $60 \mu$ of swollen protein A-Sepharose CL-4B in incubation buffer was added to the sample mixture before shaking for another $2 \mathrm{~h}$ at $4^{\circ} \mathrm{C}$. The Sepharose resin was pelleted, washed once with incubation buffer $(1 \mathrm{ml})$ and once with Tris/HCl-buffered saline solution $(100 \mathrm{mM} \mathrm{NaCl}, 10 \mathrm{mM}$ Tris/HCl pH $8 \cdot 0)$. After being vacuum-dried, proteins absorbed by the resin were solubilized with $30 \mu \mathrm{l}$ Laemmli sample buffer (Laemmli, 1970) for $10 \mathrm{~min}$ at $90^{\circ} \mathrm{C}$. Ten microlitres of solubilized protein solution of the sample was electrophoresed on SDS-polyacrylamide gel. The protein gels were stained with Coomassie blue, vacuum-dried and exposed to X-ray film. Radioactivities of the target protein bands were measured with an Ambis Radioactivity Image Reader.
Overexpression of the mutant $\sigma^{A}$ protein. To overexpress $B$. subtilis DB1005 $\sigma^{\mathrm{A}}$, the chromosomal DNA of the bacterium was extracted and used as template for amplification of the sigA DNA. Nucleotide sequences of the forward and reverse primers were 5'-CTGCAGAGATCTGAATTCGTTGCAAGCTTTGG- $3^{\prime}$ and $5^{\prime}$-CTGCAGAGATCTGTATACGCTTACAATAGAAA-3', respectively. The amplified sigA gene contains its own ribosome-binding site as well as an EcoRI and a $B g l I I$ site at the $5^{\prime}$ ends of the primers. After digesting with EcoRI and $B g l \mathrm{II}$, the sigA DNA fragment was cloned into the EcoRI and BamHI sites of the overexpression vector, pT7-5 (Tabor, 1990), to form pCT12. The sigA DNA sequence on pCT12 was examined and confirmed to be correct. Overexpression and purification of DB1005 $\sigma^{\mathrm{A}}$ protein from the culture of E. coli BL21 (DE3) were done as reported previously (Chang \& Doi, 1990).

Measurement of $\sigma^{A}$ activity in vivo at $37{ }^{\circ} \mathrm{C}$. To measure the activities of wild-type and mutant $\sigma^{A}$ factors at $37^{\circ} \mathrm{C}$, the groE promoter of B. subtilis (Li \& Wang, 1992; Schmidt et al., 1992) was first cloned into an integration vector, pCoiZA $(\mathrm{Qi}, 1990$; Qi et al., 1991). The resultant plasmid was then separately incorporated into the aprE gene of B. subtilis DB2 and DB1005. Sequences for the forward and reverse primers for the synthesis of groE promoter DNA were 5'-AGATCTGCAGAATCGCGATTAATGCGG-3' and 5'-GTTAGGATCCTCAATAGTATGAATATGT - $3^{\prime}$, respectively. The groE promoter DNA contained a PstI and a BamHI site which were used for cloning. The groE promoter DNA on the integration plasmid was sequenced and proved to be correct. $\beta$-galactosidase activities in both $B$. subtilis DB2 and DB1005 were measured by growing cells at $37^{\circ} \mathrm{C}$ in $2 \times \mathrm{SG}$ medium (Leighton \& Doi, 1971) containing erythromycin $\left(1 \mu \mathrm{g} \mathrm{ml}^{-1}\right)$, followed by harvesting at various growth stages and assaying activity by the method of Miller (1972).

RNA extraction and slot blot analysis of lacZ message. Methods for RNA extraction and quantification were as previously reported (Chang et al., 1994). The RNA samples were transferred to a piece of Hybond-N membrane (Amersham) via a vacuum blotter; methods and conditions for hybridization analysis of the RNA were as those reported for Northern blot analysis (Chang et al., 1994). The probe DNA was a lacZ DNA fragment flanked by XbaI and SstI (about $2.0 \mathrm{~kb}$ in length), which was obtained by cutting the pCoiZA plasmid with $X b a \mathrm{I}$ and $S s t \mathrm{I}$ restriction enzymes. This DNA fragment was labelled with $\left[\alpha_{-}{ }^{32} \mathrm{P}\right] \mathrm{dCTP}$ using the random priming system purchased from Boehringer Mannheim.

Effect of temperature on transcription of DB1005 $\sigma^{A}$ in vitro. Core enzyme and $\sigma^{\mathrm{A}}$ were prepared as described elsewhere (Davison et al., 1979; Fukuda \& Doi, 1977; Halling et al., 1977). Procedures for RNA polymerase holoenzyme reconstitution and in vitro transcription assay were modified according to a previously published method (Chang \& Doi, 1990). In the present study, the RNA polymerase holoenzyme was reconstituted on ice for $10 \mathrm{~min}$ by mixing $3 \mu \mathrm{l}$ core enzyme $(3 \mu \mathrm{g})$ with $3 \mu \mathrm{l}$ purified $\sigma^{\mathrm{A}}(1.5 \mu \mathrm{g})$. Afterwards, $3 \mu \mathrm{l}$ groE promoter DNA $(0 \cdot 15 \mu \mathrm{g})$ was added and the mixture was further incubated at $37^{\circ} \mathrm{C}$ for $5 \mathrm{~min}$. Following this, the RNA polymerase and promoter DNA mixture was shifted to the designated temperature $\left(32,37,42,47\right.$ or $\left.49^{\circ} \mathrm{C}\right)$ and $50 \mu \mathrm{l}$ reaction cocktail prewarmed at that temperature was then added to start the transcription reaction. The final concentration of each component in the reaction mixture was $40 \mathrm{mM}$ Tris $/ \mathrm{HCl} \mathrm{pH} \mathrm{7.9;} 10 \mathrm{mM} \mathrm{MgCl}_{2} ; 150 \mathrm{mM} \mathrm{KCl}$; $20 \mathrm{mM}$ DTT; $0.2 \mathrm{mM}$ each of UTP, CTP, GTP and ATP ; $5 \%$ glycerol; $3 \mu \mathrm{Ci}\left[\alpha-{ }^{32} \mathrm{P}\right] \mathrm{ATP}$. The transcription reaction was 
carried out at the designated temperature for $10 \mathrm{~min}$ and then an equal volume of stop solution ( $95 \%$ formamide, $20 \mathrm{mM}$ EDTA, $0.05 \%$ bromophenol blue, $0.05 \%$ xylene cyanole FF) was added. The sample of each transcription reaction was directly applied to an $8 \mathrm{M}$ urea denaturing gel for electrophoretic separation of RNA. The groE promoter DNA template was $651 \mathrm{bp}$ in length and would generate an RNA transcript of 363 bases from the transcription initiation site (Chang et al., 1994). The G3b promoter DNA of B. subtilis $\phi 29$ phage (Davison et al., 1980) was synthesized by PCR (forward and reverse primers were 5'-AGAGAACGTAGACAACAAC$3^{\prime}$ and 5'-CCTGAACCTCTCCGTCCAC-3', respectively). This promoter DNA template was $235 \mathrm{bp}$ in length and would generate a transcript of $142 \mathrm{bp}$. Radioactivity of the target transcript in each sample was measured with an Ambis Radioactivity Image Reader.

\section{RESULTS}

\section{The half-lives of wild-type and mutant $\sigma^{A}$ factors}

It is generally believed that hydrophobic interactions in the core region of some proteins are essential to their integrity. The promoter -10 binding region is within the most hydrophobic part of $\sigma^{\mathrm{A}}$ protein (Chang \& Doi, 1990), thus the two amino acid substitutions (I198A and I202A) (Fig. 1) which change the hydrophobicity of this region could affect the structural stability and degradability of $\sigma^{\mathrm{A}}$, especially at elevated temperatures. To verify this, the degradation rates of both wild-type and mutant $\sigma^{\mathrm{A}}$ proteins were analysed in vivo. In the experiments, the total cellular proteins of $B$. subtilis DB2 and DB1005 were pulse-labelled at designated time points at both 37 and $49^{\circ} \mathrm{C}$ followed by immunoprecipitation with anti- $\sigma^{\mathrm{A}}$ and anti-GroEL. Radioactivities of the protein bands corresponding to $\sigma^{\mathrm{A}}$ and GroEL were read with a radioactivity image reader after SDS-PAGE. Percentages of $\sigma^{\mathrm{A}}$ and GroEL remaining in the cells at each time point were calculated. The rate of GroEL degradation was used as an internal standard to monitor the performance of our experiments. The degradation rates of wild-type and mutant $\sigma^{\mathrm{A}}$, as well as the degradation rates of GroEL in both DB2 and DB1005 at $37{ }^{\circ} \mathrm{C}$ are depicted in Fig. 2(a, c). Their half-lives, calculated according to the regression lines in Fig. 2(a, c), are shown in Table 1 . We found that the degradation rates of GroEL at $37^{\circ} \mathrm{C}$ in both $\mathrm{DB} 2\left(t_{1 / 2} 158 \mathrm{~min}\right)$ and $\operatorname{DB} 1005\left(t_{1 / 2} 152 \mathrm{~min}\right)$ were similar; however, the rates of $\sigma^{\mathrm{A}}$ degradation in these two strains were different. The relatively constant amount of labelled $\sigma^{\mathrm{A}}$ remaining in $\mathrm{DB} 2$ at $37^{\circ} \mathrm{C}$ indicated that the wild-type $\sigma^{\mathrm{A}}$ was fairly stable $\left(t_{1 / 2}>600 \mathrm{~min}\right)$ at this temperature. In constrast, the rapid decrease in the amount of labelled $\sigma^{\mathrm{A}}$ in DB1005 indicates that the mutant $\sigma^{\mathrm{A}}$ is relatively unstable $\left(t_{1 / 2} 59 \mathrm{~min}\right)$, even at the permissive temperature.

The degradation rates of $\sigma^{\mathrm{A}}$ and GroEL at $49^{\circ} \mathrm{C}$ are shown in Fig. 2(b, d). The half-lives of GroEL in DB2 and DB1005, calculated according to the regression lines in Fig. 2(b, d) were about 42 and $57 \mathrm{~min}$, respectively (Table 1). Moreover, two phases of $\sigma^{\mathrm{A}}$ degradation were observed in these two strains (Fig. 2b). The first phase was detected within the initial $40 \mathrm{~min}$ after the upshift of temperature to $49^{\circ} \mathrm{C}$. In this phase, the degradation of wild-type $\sigma^{\mathrm{A}}$ in $B$. subtilis DB2 accelerated, with a halflife of about $34 \mathrm{~min}$ (Table 1). A similar magnitude of half-life was observed for the mutant $\sigma^{\mathrm{A}}$ in DB1005 $\left(t_{1 / 2}\right.$ $23 \mathrm{~min}$ ). These results indicate that both wild-type and mutant $\sigma^{\mathrm{A}}$ become unstable and more susceptible to protease after temperature elevation. The second phase of $\sigma^{\mathbf{A}}$ degradation was manifested after a prolonged incubation of the labelled cells at $49^{\circ} \mathrm{C}$. The percentages of labelled $\sigma^{\mathrm{A}}$ in the two strains remained fairly constant in this phase; however, a higher percentage of $\sigma^{\mathrm{A}}$ persisted in DB2 as compared with that in DB1005 (Fig. $2 b)$. The reason for the occurrence of the second phase of $\sigma^{\mathrm{A}}$ degradation is unclear. One possibility is that a certain proportion of the labelled $\sigma^{\mathrm{A}}$ proteins, both wildtype and mutant, fail to dissociate from the RNA polymerase holoenzyme and are therefore protected from being degraded at the elevated temperature. Alternatively, it could represent the stabilizing effect of chaperonins induced under heat shock.

The lower degradation half-life of DB1005 $\sigma^{\mathrm{A}}$ could be due to the presence of intracellular proteases in the cells. The participation of the major intracellular protease, IspI, (Kiode et al., 1986) in the degradation of $\sigma^{\mathrm{A}}$ in $B$. subtilis DB1005 was investigated by comparing the half-lives of the mutant $\sigma^{\mathrm{A}}$ in both $B$. subtilis DB1005 $\left(i s p^{+}\right.$) and DB435 (isp) containing the same Ts sigA allele. Our data showed that $\sigma^{\mathrm{A}}$ in B. subtilis DB435 was degraded to a lesser extent than in DB1005 (Fig. 2a, b). The half-lives of $\sigma^{\mathrm{A}}$ in DB435 were slightly longer than those for B. subtilis DB1005 at both 37 and $49{ }^{\circ} \mathrm{C}(80$ vs $59 \mathrm{~min}$ and 25 vs $23 \mathrm{~min}$ at 37 and $49^{\circ} \mathrm{C}$, respectively) (Table 1). Since B. subtilis DB435 and DB1005 showed a similar Ts phenotype, it appeared that the partially improved half-life of the mutant $\sigma^{\mathrm{A}}$ in the isp background could not alleviate the Ts phenotype.

\section{B. subtilis DB1005 compensates for $\sigma^{\mathrm{A}}$ instability by increasing $\sigma^{A}$ synthesis at $37^{\circ} \mathrm{C}$ but not at $49{ }^{\circ} \mathrm{C}$}

$\sigma^{\mathrm{A}}$ in B. subtilis DB1005 was unstable at both 37 and $49^{\circ} \mathrm{C}$ (Fig. 2, Table 1); however, it was only at $49^{\circ} \mathrm{C}$ that the detrimental effect on growth was manifested (Chang \& Doi, 1993b; Chang et al., 1994). The difference is intriguing. A plausible answer to this puzzle based on our previous observations of a higher $\sigma^{\mathrm{A}}$ concentration in DB1005 relative to that in DB2 at $37{ }^{\circ} \mathrm{C}$ (Chang et al., 1994) is that DB1005 may compensate for unstable $\sigma^{\mathrm{A}}$ by synthesizing and maintaining a sufficient concentration of $\sigma^{\mathrm{A}}$ in the cells at $37^{\circ} \mathrm{C}$ but not at $49^{\circ} \mathrm{C}$. In other words, the temperature sensitivity of $B$. subtilis DB1005 at $49^{\circ} \mathrm{C}$ was probably caused by its inability to sustain a sufficient concentration of $\sigma^{\mathrm{A}}$ in the cells. To verify this, we compared the residual amounts of the pulse-labelled $\sigma^{\mathrm{A}}$ and the rates of $\sigma^{\mathrm{A}}$ synthesis in both DB2 and DB1005 at different intervals since the cellular concentration of a protein is affected by its rates of degradation and synthesis at a specific time point. At $37^{\circ} \mathrm{C}$, the labelled $\sigma^{\mathrm{A}}$ remaining in DB1005 was higher relative to that in DB2 at each time point tested (Table 
(a)

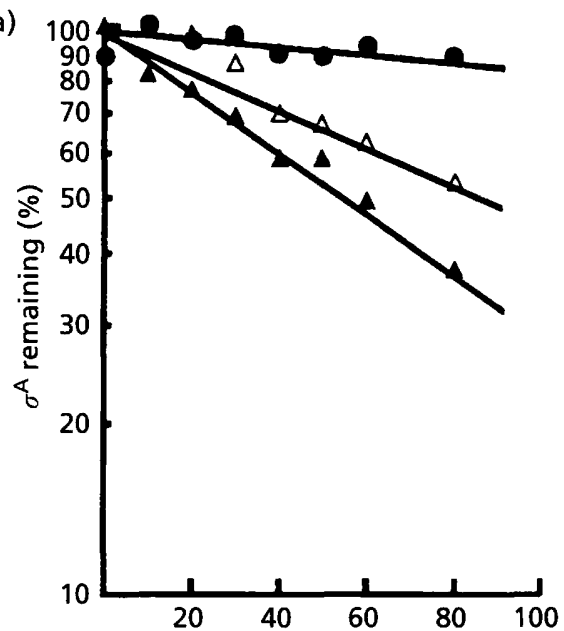

(c)

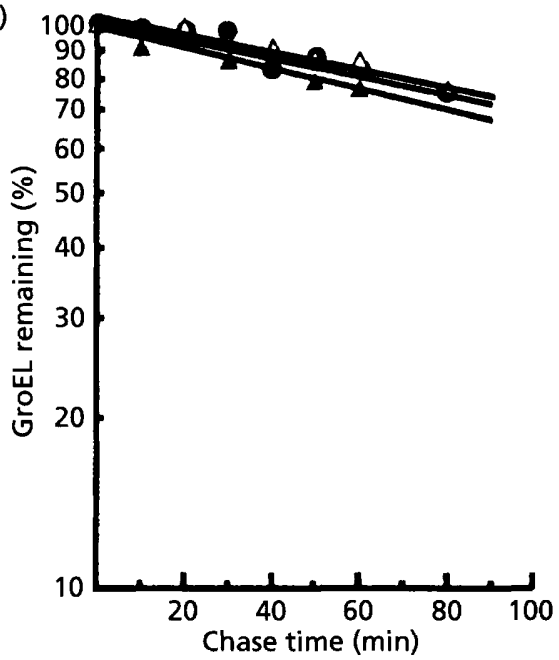

(b)

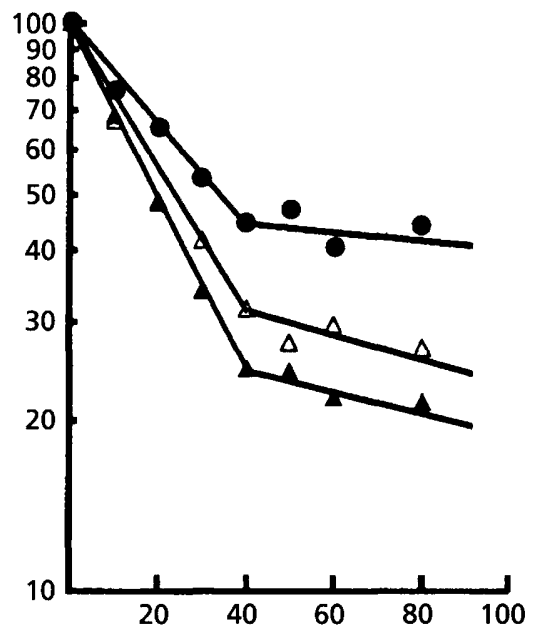

(d)

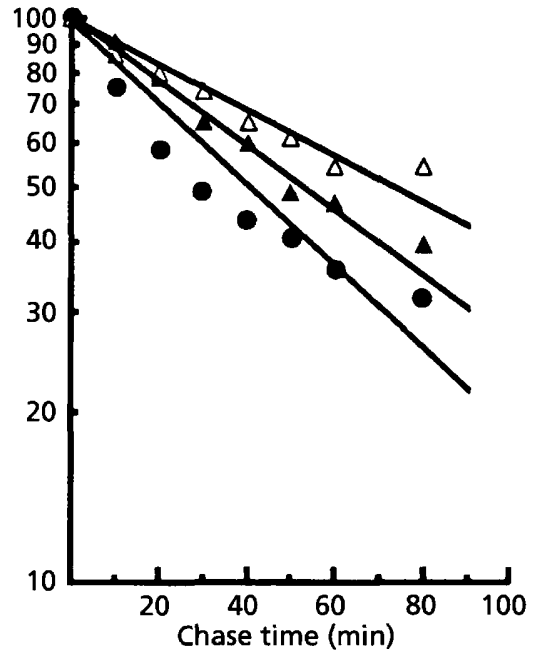

Fig. 2. Degradation of $\sigma^{A}$ and GroEL proteins. (a, b) Regression lines of the means of triplicate determinations of $\sigma^{A}$ remaining in the cells at (a) $37^{\circ} \mathrm{C}$ and (b) $49^{\circ} \mathrm{C}$. (c, d) Regression lines of the means of triplicate determinations of GroEL remaining in the cells at (c) $37{ }^{\circ} \mathrm{C}$ and (d) $49^{\circ} \mathrm{C}$. Standard deviations were $10 \%$ of the means. Each data point represents the ratio of the radioactivity of $\sigma^{A}$ or GroEL to that at time zero. Measurements for each regression line were repeated at least twice and were reproducible. $\bullet, D B 2 ; \mathbf{\Delta}, D B 1005 ; \triangle, D B 435$.

Table 1. Degradation of SigA and GroEL in Bacillus subtilis

\begin{tabular}{|c|c|c|c|c|c|}
\hline \multirow[t]{3}{*}{ Strain } & \multirow{3}{*}{$\begin{array}{l}\text { Relevant } \\
\text { genotype }\end{array}$} & \multicolumn{4}{|c|}{ Half-life $(\mathrm{min})^{*}$} \\
\hline & & \multicolumn{2}{|c|}{$37^{\circ} \mathrm{C}$} & \multicolumn{2}{|c|}{$49^{\circ} \mathrm{C}$} \\
\hline & & SigA & GroEL & SigA & GroEL \\
\hline DB2 & $\operatorname{sig} A$ (wild-type) & $>600$ & 158 & 34 & 42 \\
\hline DB1005 & $\operatorname{sig} A(\mathrm{Ts})$ & 59 & 152 & 23 & 57 \\
\hline DB435 & $\operatorname{sig} A$ (Ts) npr apr epr bpf ispI & 80 & 171 & 25 & 74 \\
\hline
\end{tabular}

"Determined according to the regression lines in Fig. 2. 
Table 2. Relative amounts of SigA remaining and synthesized in Bacillus subtilis

Each value is the ratio of the radioactivity of labelled SigA in DB1005 to that in DB2 at the designated time point.

\begin{tabular}{|c|c|c|c|c|}
\hline \multirow[t]{2}{*}{$\begin{array}{l}\text { Time } \\
(\min )\end{array}$} & \multicolumn{2}{|c|}{$\begin{array}{l}\text { SigA remaining* } \\
\text { (DB1005/DB2) }\end{array}$} & \multicolumn{2}{|c|}{$\begin{array}{l}\text { SigA synthesized }+ \\
\text { (DB1005/DB2) }\end{array}$} \\
\hline & $37^{\circ} \mathrm{C}$ & $49^{\circ} \mathrm{C}$ & $37^{\circ} \mathrm{C}$ & $49^{\circ} \mathrm{C}$ \\
\hline 0 & $2 \cdot 46$ & 0.92 & $1.85(1.00)$ & 1.06 \\
\hline 10 & $2 \cdot 01$ & $0 \cdot 83$ & $1.54(0.96)$ & - \\
\hline 20 & 1.95 & $0 \cdot 68$ & $1.89(0.94)$ & - \\
\hline 30 & $1 \cdot 60$ & 0.58 & $1.60(0.92)$ & - \\
\hline 40 & $1 \cdot 46$ & 0.51 & $2.02(0.89)$ & - \\
\hline 50 & $1 \cdot 35$ & $0 \cdot 48$ & $2.46(0.87)$ & - \\
\hline 60 & $1 \cdot 18$ & $0 \cdot 50$ & $1.92(0.88)$ & - \\
\hline 80 & $0 \cdot 97$ & $0 \cdot 44$ & $2.66(0.83)$ & - \\
\hline
\end{tabular}

- , Not measured.

*Relative amount of SigA remaining in the cell after chasing. Each value was determined on the basis of the data shown in Fig. 2.

† The cells were pulse-labelled at the designated time points for 5 min before sampling and determination of the amount of labelled SigA protein. Numbers in parentheses indicate the ratios of the $\mathrm{OD}_{550}$ of DB1005 to that of DB2.

2). The ratio of labelled $\sigma^{\mathrm{A}}$ remaining in DB1005 and DB2 was about 2.46 to 0.97 within the $80 \mathrm{~min}$ interval and the relative amount of $\sigma^{\mathrm{A}}$ synthesized in DB1005 was at least 1.5 -fold higher than that in DB2 at the same intervals at $37^{\circ} \mathrm{C}$. The higher residual amount of $\sigma^{\mathrm{A}}$, along with the higher rate of $\sigma^{\mathrm{A}}$ synthesis in DB1005 implied that DB1005 was able to compensate for $\sigma^{A}$ instability by synthesizing and maintaining a sufficient concentration of this factor in the cells at $37^{\circ} \mathrm{C}$.

The relative amount of labelled $\sigma^{\mathrm{A}}$ remaining in DB1005 and DB2 at $49^{\circ} \mathrm{C}$ is also shown in Table 2 . In contrast to the results observed at $37^{\circ} \mathrm{C}$, the amount of labelled $\sigma^{\mathrm{A}}$ remaining in DB1005 was less than that found in DB2. The ratio of $\sigma^{\mathrm{A}}$ remaining in DB1005 and in DB2 ranged from about $0 \cdot 92: 1$ to $0 \cdot 44: 1$ within the $80 \mathrm{~min}$ interval (Table 2). The ratio of the amount of $\sigma^{\mathrm{A}}$ synthesized in DB1005 and in DB2 was about 1.06 to 1 at 9 min after the upshift of temperature to $49{ }^{\circ} \mathrm{C}$, which was much lower than the ratio of 1.85 to 1 obtained at $37^{\circ} \mathrm{C}$ (Table 2). The synthesis of $\sigma^{\mathrm{A}}$ in $B$. subtilis DB1005 after a longer exposure to $49^{\circ} \mathrm{C}$ was not measured due to the fact that DB1005 was unable to grow at $49^{\circ} \mathrm{C}$ and the amount of $\sigma^{\mathrm{A}}$ in DB1005 decreased within the $120 \mathrm{~min}$ interval after the upshift of temperature from 37 to $49^{\circ} \mathrm{C}$ in GMM (Chang et al., 1994). All these results indicate that $B$. subtilis DB1005 is unable to sustain the concentration of $\sigma^{\mathrm{A}}$ at $49^{\circ} \mathrm{C}$. However, it remained unclear whether this was the cause of the temperature sensitivity of B. subtilis DB1005. (a)

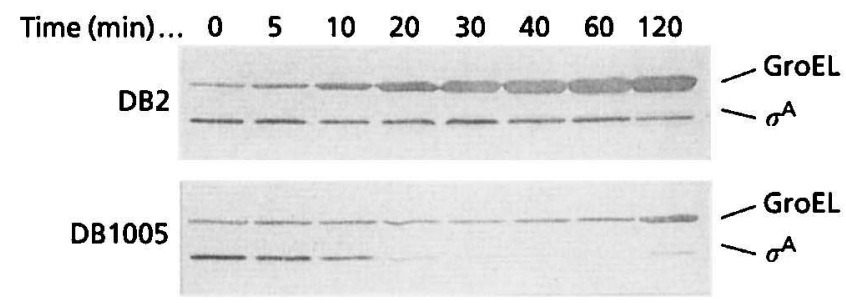

(b)

$2 \times S G$ GMM

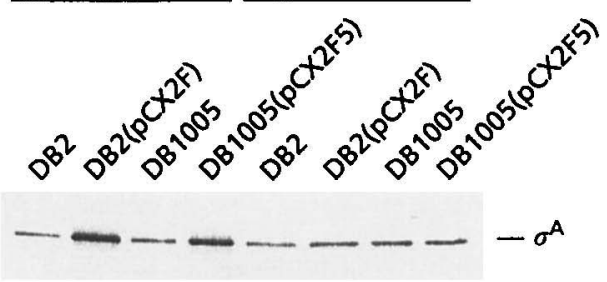

(c)

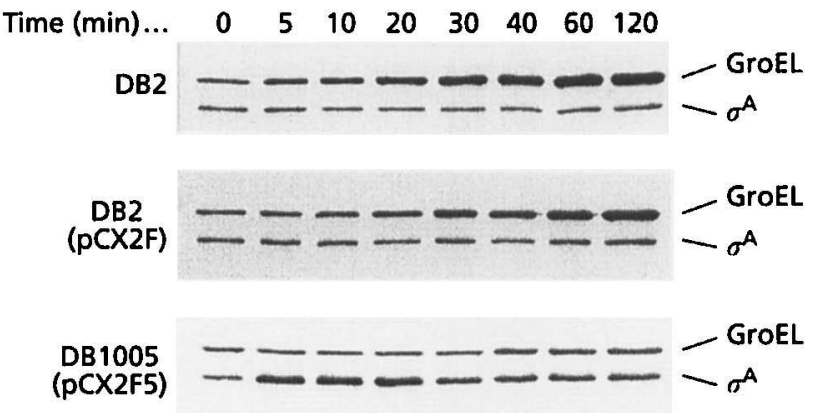

Fig. 3. Immunoblot analyses of $\sigma^{\mathrm{A}}$ and GroEL levels in $B$. subtilis. (a) Levels of $\sigma^{A}$ and GroEL in B. subtilis DB2 and DB1005 before and after temperature elevation. $B$. subtilis strains were grown in $2 \times S G$ at $37^{\circ} \mathrm{C}$ to an $O D_{550}$ of 0.4 (referred to as time zero) and then shifted to $49^{\circ} \mathrm{C}$. A $1 \mathrm{ml}$ cell sample was harvested at the time points indicated above the panels. After resuspending the cell pellet in $50 \mu \mathrm{l} 0.5 \times$ SET buffer $(20 \%$ sucrose, $50 \mathrm{mM}$ Tris/ $\mathrm{HCl}$ pH 7.6, $50 \mathrm{mM}$ EDTA, $2 \mathrm{mM}$ PMSF) and digestion of the cell wall with lysozyme, $50 \mu \mathrm{l}$ sample application buffer (Chang \& Doi, 1990) was added to rupture the cells. Five microlitres of the cell lysate were then used for immunoblot analysis. (b) Expression of $\sigma^{A}$ in $B$. subtilis harbouring plasmids $\mathrm{pCX} 2 \mathrm{~F}$ or $\mathrm{pCX} 2 \mathrm{~F} 5$ at $37^{\circ} \mathrm{C}$. B. subtilis strains were grown in $2 \times \mathrm{SG}$ or $\mathrm{GMM}$ at $37^{\circ} \mathrm{C}$, harvested at an $\mathrm{OD}_{550}$ of 0.4 and treated as in (a). Five microlitres (for $2 \times \mathrm{SG}$ ) or $7 \mu \mathrm{l}$ (for GMM) of the cell lysate were used for immunoblot analysis. (c) Levels of $\sigma^{\mathrm{A}}$ and GroEL in $B$. subtilis harbouring plasmids $\mathrm{pCX} 2 \mathrm{~F}$ or $\mathrm{pCX} 2 \mathrm{~F} 5$ before and after temperature elevation. B. subtilis strains were grown in GMM at $37^{\circ} \mathrm{C}$ to an $\mathrm{OD}_{550}$ of 0.4 (referred to as time zero) and then transferred to $49^{\circ} \mathrm{C}$. Cell samples were harvested and treated as in (a). Five microlitres of the cell lysate were used for immunoblot analysis.

\section{Insufficient $\sigma^{A}$ concentration is not the cause of the temperature sensitivity of $B$. subtilis DB1005}

To verify the relationship between the cellular concentration of $\sigma^{\mathrm{A}}$ and the temperature sensitivity of $B$. subtilis DB1005, we compared the levels of $\sigma^{\mathrm{A}}$ in $B$. subtilis DB1005 and DB2 grown in $2 \times \mathrm{SG}$ medium 


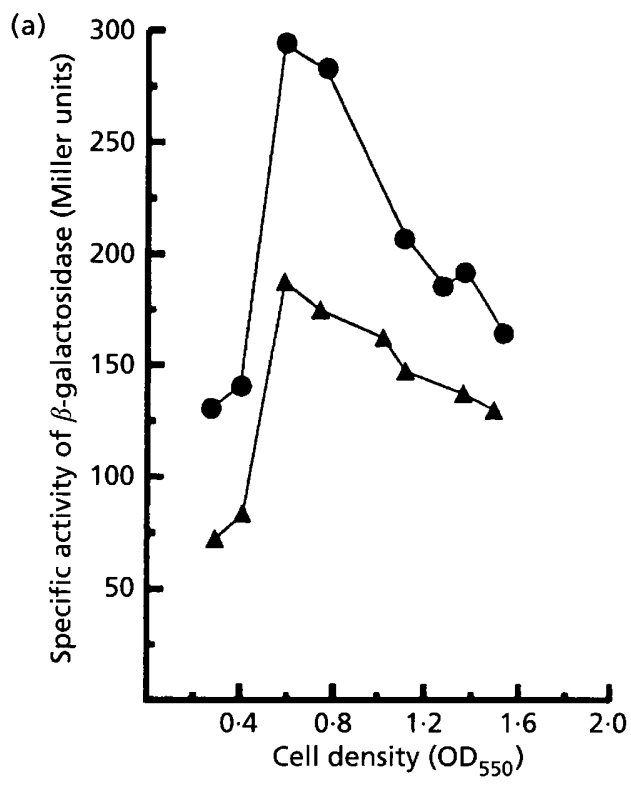

(b) $\quad 37^{\circ} \mathrm{C} \quad 49^{\circ} \mathrm{C}$ $(1.77) \quad(5.31)$

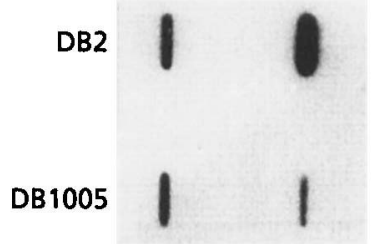

Fig. 4. Transcriptional activities of the wild-type and mutant $\sigma^{A}$ on the groE promoter in vivo. (a) Determination of $\sigma^{A}$ activity at $37^{\circ} \mathrm{C}$ by a lacZ transcriptional gene fusion. B. subtilis DB2 (O) and DB1005 $(\boldsymbol{A})$ cells in which the pCoiZA-derived plasmid (containing the groE promoter DNA) has been integrated into the chromosome were grown in $2 \times \mathrm{SG}$ medium at $37^{\circ} \mathrm{C}$ with shaking. Triplicate samples were removed from each culture at the designated $O D_{550}$ and assayed for $\beta$-galactosidase activity. Each data point represents the mean value of three parallel samples. (b) Slot blot analysis of $\sigma^{A}$ activity at both 37 and $49^{\circ} \mathrm{C}$. Total RNA was extracted from cultures of DB2 and DB1005 grown at $37^{\circ} \mathrm{C}$ to an $O D_{550}$ of 0.7 and from the same cultures $10 \mathrm{~min}$ after upshifting of the temperature to $49^{\circ} \mathrm{C}$. Ten micrograms of each RNA sample was applied to a Hybond$\mathrm{N}$ membrane with a vacuum blotter and probed with ${ }^{32} \mathrm{P}$ labelled lacZ DNA prepared by a random priming method. The radioactivity of each sample on the membrane was counted with a radioactivity image reader. The numbers shown in parentheses below the designated temperatures are the ratios of wild-type and mutant $\sigma^{\mathrm{A}}$ activities obtained by dividing the radioactivity of lacZ mRNA in DB2 by that in DB1005.

before and after heat shock. Similar to previous observations (Chang \& Doi, 1993b), there was a transient reduction of $\sigma^{\mathrm{A}}$ in both DB2 and DB1005, but the degree of reduction was quite moderate in DB2. The level of $\sigma^{A}$ in B. subtilis DB1005 was higher than that in DB2 before the upshift of temperature, which is consistent with the observation that DB1005 has a higher $\sigma^{\mathrm{A}}$ synthesis rate at $37^{\circ} \mathrm{C}$ (Table 2). However, the level of $\sigma^{\mathrm{A}}$ in DB1005 dropped quite drastically relative to DB2 after a longer exposure to $49^{\circ} \mathrm{C}$ (Fig. 3a). Since DB1005 stopped growing rapidly upon temperature upshift while the levels of $\sigma^{\mathrm{A}}$ were still high, it seemed that the temperature sensitivity of $B$. subtilis DB1005 was probably not due to insufficient $\sigma^{\mathrm{A}}$ concentration. To highlight this point, we introduced the pCX2F and pCX2F5 plasmids (see Methods) into B. subtilis DB2 and DB1005, respectively, to increase the level of $\sigma^{\mathrm{A}}$ in the cells. The increase was much more pronounced in $2 \times \mathrm{SG}$ medium than in GMM for both B. subtilis $\mathrm{DB} 2(\mathrm{pCX} 2 \mathrm{~F})$ and DB1005(pCX2F5) at $37^{\circ} \mathrm{C}$ (Fig. 3b). However, $B$. subtilis DB1005(pCX2F5) failed to grow in both media after temperature upshift (data not shown), even after the marked increase in the amount of $\sigma^{\mathrm{A}}$. In fact, there was an induction of $\sigma^{\mathrm{A}}$ synthesis in DB1005 (pCX2F5) at high temperature and the level of $\sigma^{\mathrm{A}}$ was much higher in DB1005 (pCX2F5) than that in DB2 or in DB2(pCX2F) at parallel time points after temperature elevation (Fig. $3 c)$. The inability of a higher level of $\sigma^{\mathrm{A}}$ to suppress the Ts phenotype demonstrates that the temperature sensitivity of $B$. subtilis DB1005 is not due to insufficient $\sigma^{\mathrm{A}}$ concentration.

\section{DB1005 $\sigma^{\mathrm{A}}$ has a markedly lower activity at $49{ }^{\circ} \mathrm{C}$}

We have observed that the accumulation of GroEL in $B$. subtilis DB1005 under heat stress was very slow both in the presence and absence of pCX2F5 (Fig. 3a, c). These results reflected the fact that the mutant $\sigma^{\mathrm{A}}$ lost a considerable amount of activity after temperature elevation. To examine the relative activity of the mutant $\sigma^{\mathrm{A}}$, we transcriptionally fused the $g r o E$ promoter $\left(\sigma^{\mathrm{A}}\right.$ type) (Chang et al., 1994; Li \& Wang, 1992; Schmidt et al., 1992) to the lac $Z$ gene and integrated this construct into both $B$, subtilis DB2 and DB1005, respectively. Our data showed that the extent of LacZ activity was always greater (by about 1.5 -fold) in DB2 than in DB1005 during growth at $37^{\circ} \mathrm{C}$ (Fig. 4a). Consistent with this finding about 1.77 -fold more lac Z mRNA was observed in DB2 than in DB1005 at $37^{\circ} \mathrm{C}$ at about the same cell density (Fig. 4b). Since $\beta$-galactosidase was inactivated at $49^{\circ} \mathrm{C}$, only the amounts of lacZ mRNA synthesized in both DB2 and DB1005 at this temperature were compared (Fig. 4b). We found that the lac $\mathrm{Z}$ mRNA was sharply elevated in DB2 after temperature elevation, whereas it was reduced in DB1005. It was about 5.31fold higher in DB2 than in DB1005. These results indicate that temperature elevation has a profound adverse effect on the activity of $B$. subtilis DB1005 $\sigma^{\mathrm{A}}$.

The effect of temperature elevation on the relative activity of DB1005 $\sigma^{\mathrm{A}}$ in vitro is shown in Fig. 5. No induction of groE message was observed for reactions containing the wild-type $\sigma^{\mathrm{A}}$ above $37^{\circ} \mathrm{C}$. The activities of both wild-type and mutant $\sigma^{\mathrm{A}}$ factors on the same groE promoter peaked at $37^{\circ} \mathrm{C}$ and declined as the temperature was elevated (Fig. $5 \mathrm{a}, \mathrm{c}$ ). In addition, there was a slight increase in the ratio of wild-type to mutant $\sigma^{\mathrm{A}}$ activity (from 3.6 to 4.1 ) as the reaction temperature was increased from 32 to $49^{\circ} \mathrm{C}$ (Fig. 5c). Similarly, the activities of wild-type and mutant $\sigma^{\mathrm{A}}$ factors on the 
(a)

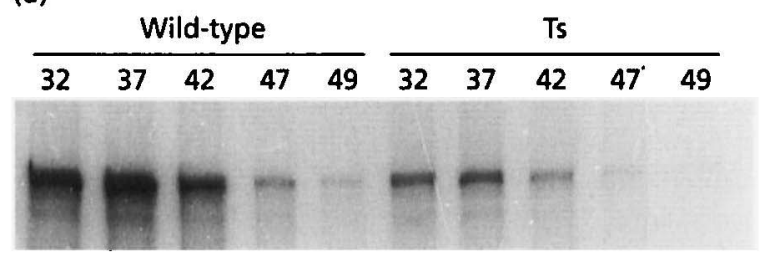

(c)

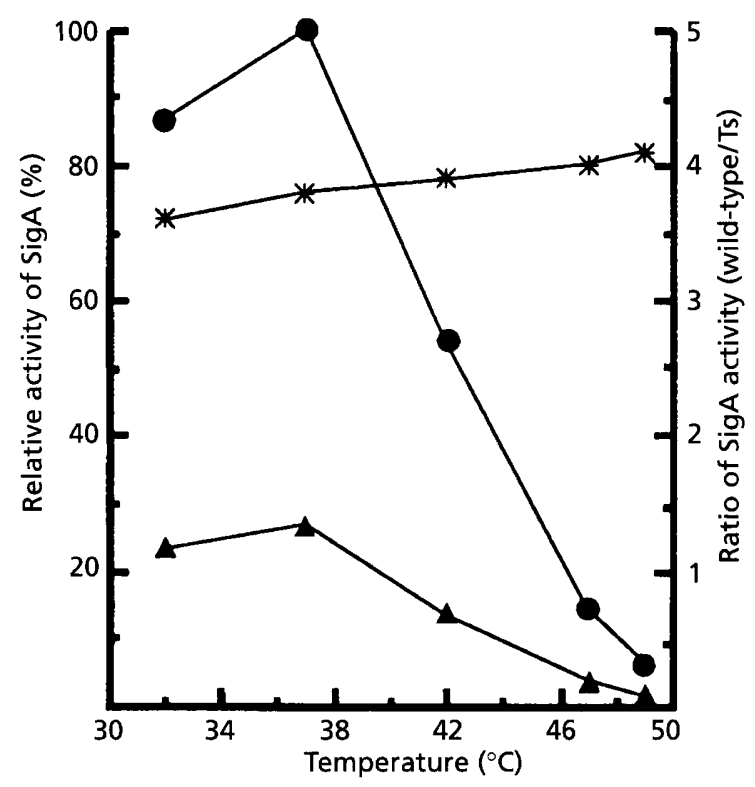

(b)

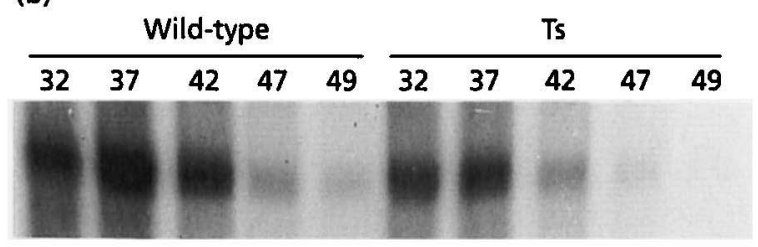

(d)

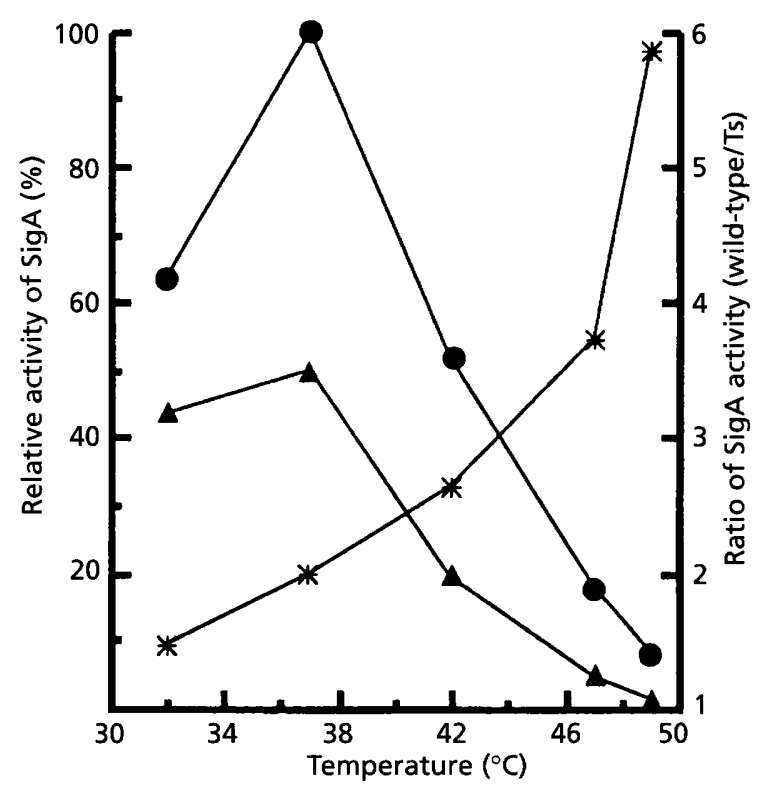

Fig. 5. Effect of temperature elevation on transcriptional activity of the wild-type and Ts $\sigma^{A}$ in vitro. (a, b) Autoradiograms of mRNA transcripts from in vitro transcription of (a) B. subtilis groE promoter and (b) phage $\phi 29$ G3b promoter. The numbers above the panels are the temperatures being tested. The conditions for in vitro transcription reactions are given in Methods. (c, d) Relative activities of wild-type $(\boldsymbol{\theta})$ and Ts $(\boldsymbol{\Lambda}) \sigma^{\mathcal{A}}$ factors on (c) groE promoter and (d) G3b promoter at various temperatures. The activity of wild-type $\sigma^{\mathrm{A}}$ at $37^{\circ} \mathrm{C}$ was taken as $100 \%$. $*$, Ratio of wild-type to Ts $\sigma^{\AA}$ activity.

strong G3b promoter of $B$. subtilis $\phi 29$ phage peaked at $37^{\circ} \mathrm{C}$. Moreover, the ratio of wild-type to mutant $\sigma^{A}$ activity increased from 1.5 to 5.8 as the temperature was raised from 32 to $49^{\circ} \mathrm{C}$ (Fig. $5 \mathrm{~b}, \mathrm{~d}$ ). Therefore, it was clear that the mutant $\sigma^{\mathrm{A}}$ factor was much less active than the wild-type counterpart at higher temperatures. The correlation between the markedly lower $\sigma^{\mathrm{A}}$ activity and the temperature sensitivity of $B$. subtilis DB1005 at $49^{\circ} \mathrm{C}$ suggests that the level of activity of $\sigma^{\mathrm{A}}$ is the limiting factor for DB1005 growth at high temperature. Furthermore, the lack of induction of groE message in vitro in the presence of wild-type $\sigma^{\mathrm{A}}$ above $37^{\circ} \mathrm{C}$ was probably due to the absence of repressors (Yuan \& Wong, 1995) in the system, which thus allowed the groE promoter to express constitutively.

\section{DISCUSSION}

Analyses of the biochemical properties of the mutant $\sigma^{\mathrm{A}}$ factor in B. subtilis DB1005 at both permissive and restrictive temperatures have revealed that it is struc- turally unstable and easily degraded, even at the permissive temperature. In addition, the transcriptional activity of the mutant $\sigma^{\mathrm{A}}$ is markedly lower than that of the wild-type counterpart at both temperatures. These results indicate that the two hydrophobic isoleucine residues at positions 198 and 202 are crucial to the structural and functional properties of B. subtilis $\sigma^{\mathrm{A}}$ factor.

Unlike the $\sigma^{70}$ of $E$. coli, the synthesis of which increases three- to fivefold during heat shock (Taylor et al., 1984), the synthesis of $B$. subtilis $\sigma^{\mathrm{A}}$ factor was sharply repressed when the cells were subjected to heat shock (Arnosti et al., 1986). Similar to the results reported previously, a transient decrease in $\sigma^{\mathrm{A}}$ concentration was observed for both B. subtilis DB2 and DB1005; however, the process lasted much longer in B. subtilis DB1005 than in DB2 (Fig. 3a). The longer duration should not be viewed mainly as the result of rapid degradation of $\sigma^{\mathbf{A}}$ in DB1005 since the wild-type and mutant $\sigma^{\mathrm{A}}$ factors have comparable half-lives at high temperature (Table 1). 
The most probable cause is the loss of activity of the mutant $\sigma^{\mathrm{A}}$ whose synthesis is believed to be selfcontrolled transcriptionally during vegetative growth unless the P1P2 promoter of the B. subtilis sigA operon is transcriptionally blocked (Hicks \& Grossman, 1995). The phenomenon of loss of $\sigma^{\mathrm{A}}$ activity correlating with transient reduction of protein was also observed for GroEL in DB1005 (Fig. 3a).

$\sigma^{\mathrm{A}}$ in B. subtilis DB1005 was unstable both at permissive and restrictive temperatures (Table 1). However, it was detrimental to the growth of DB1005 only at high temperature. It seems impossible that this phenomenon is due to insufficient $\sigma^{\mathrm{A}}$ concentration in the cells at $49^{\circ} \mathrm{C}$ since overexpression of the mutant $\sigma^{\mathrm{A}}$ was unable to suppress the Ts phenotype of B. subtilis DB1005 (Fig. $3 \mathrm{~b}, \mathrm{c})$. Other lines of evidence supporting this fact are the presence of a significant amount of $\sigma^{\mathcal{A}}$ in B. subtilis DB1005 before temperature upshift (Fig. 3a), and the failure of a partially improved half-life of the mutant $\sigma^{A}$ in the background of major intracellular protease mutation (isp) of $B$. subtilis to alleviate the Ts phenotype (Fig. 2, Table 1). Hence, the temperature sensitivity of $B$. subtilis DB1005 must be due to low activity of the mutant $\sigma^{\mathrm{A}}$ at $49^{\circ} \mathrm{C}$. In other words, the sharp decline in an already reduced activity of DB1005 $\sigma^{\mathrm{A}}$ might lead to a markedly lower activity of the mutant $\sigma^{\mathrm{A}}$ at $49^{\circ} \mathrm{C}$ (Figs 4,5 ), which is probably below a critical level necessary for DB1005 growth. This idea was supported by the restoration of DB1005 growth at high temperature by two different intragenic suppressors of sigA through partially enhanced $\sigma^{\mathrm{A}}$ activity (B.-Y. Chang, unpublished results). Thus, the cessation of DB1005 growth soon after temperature upshift $\left(37\right.$ to $49^{\circ} \mathrm{C}$ ) might be the symptom of the adverse effect of high temperature on the activity of DB1005 $\sigma^{\mathrm{A}}$, while the resumption of growth after temperature downshift $\left(49\right.$ to $37^{\circ} \mathrm{C}$ ) might indicate the elimination of this adverse effect. Consequently, we conclude that the temperature sensitivity of $B$. subtilis DB1005 is mainly due to low activity rather than insufficient concentration of $\sigma^{\mathrm{A}}$ in DB1005 at high temperature. Therefore, the nature of the Ts mutation in B. subtilis DB1005 is evidently different from that of the E. coli rpoD 800 Ts mutant. The Ts phenotype of this E. coli strain can be ascribed to insufficient $\sigma^{70}$ concentration rather than altered function of the $\sigma^{70}$ protein, since it can be suppressed by mutations in the lon protease gene (Grossman et al., 1983; Liebke et al., 1980).

Other important observations in our studies are the compensation of $\sigma^{\mathrm{A}}$ in B. subtilis DB1005 at $37^{\circ} \mathrm{C}$ (Table 2) and the induction of $\sigma^{A}$ synthesis in B. subtilis DB1005(pCX2F5) within $5 \mathrm{~min}$ after temperature upshift (Fig. 3a). The increased level of $\sigma^{\mathrm{A}}$ at $37^{\circ} \mathrm{C}$ was also observed in two other sigA mutants in which proline or glycine residues had been introduced into the promoter -10 binding region of $\sigma^{\mathrm{A}}$ (B.-Y. Chang, unpublished results). It seems that there is an unknown autogenous control of the level of $\sigma^{\mathrm{A}}$ in B. subtilis. One possibility is that this control is carried out by transcription from promoters other than $\mathrm{P} 1 \mathrm{P} 2$ on the sigA operon, as reported for the csh203:: Tn917lac mutant of B. subtilis in which the minor $\sigma$ factor $\sigma^{\mathbf{H}}$ becomes essential for the expression of $\sigma^{\mathrm{A}}$ and for vegetative growth (Hicks \& Grossman, 1995). The induction of $\sigma^{\mathrm{A}}$ synthesis in $B$. subtilis $\mathrm{DB} 1005$ (pCX2F5) at $49^{\circ} \mathrm{C}$ was unexpected since the mutant $\sigma^{\mathrm{A}}$ lost most of its activity at the elevated temperature (Figs 4,5 ) and no such induction was observable in B. subtilis DB1005 under heat stress (Fig. 3a). Most likely, the induction is closely related to the expression of plasmid-borne 'mutant $\sigma^{\mathrm{A}}$ ' in B. subtilis $\mathrm{DB} 1005(\mathrm{pCX} 2 \mathrm{~F} 5)$, otherwise similar induction should also be observed in $\mathrm{DB} 2(\mathrm{pCX} 2 \mathrm{~F})$ under the same conditions (Fig. 3c). The mechanism of $\sigma^{\mathrm{A}}$ induction in $\mathrm{DB} 1005$ (pCX2F5) at the elevated temperature and its relation, if any, to the regulation of the $\operatorname{sig} A$ gene in $B$. subtilis DB1005 remain unclear. Further experiments are needed to answer these questions.

\section{ACKNOWLEDGEMENTS}

We thank K.Y. Lee and R.H. Doi for reviewing the manuscript. This research was supported by National Science Council of the Republic of China grant NSC 84-2311B005-031.

\section{REFERENCES}

Arnosti, D. N., Singer, V. L. \& Chamberlin, M. J. (1986). Characterization of heat shock in Bacillus subtilis. J Bacteriol 168, 1243-1249.

Brennan, R. G. \& Matthews, B. W. (1989). The helix-turn-helix DNA-binding motif. J Biol Chem 264, 1903-1906.

Burgess, R. R., Travers, A. A., Dunn, J. J. \& Bautz, E. K. F. (1969). Factor stimulating transcription by RNA polymerase. Nature 221, 43-46.

Chak, K. F., de Lencastre, H., Liu, H.-M. \& Piggot, P. J. (1982). Facile in vivo transfer of mutations between the Bacillus subtilis chromosome and a plasmid harbouring homologous DNA. J Gen Microbiol 128, 2813-2816.

Chang, B.-Y. \& Doi, R. H. (1990). Overproduction, purification, and characterization of the Bacillus subtilis RNA polymerase $\sigma^{\mathrm{A}}$ factor. J Bacteriol 172, 3257-3263.

Chang, B.-Y. \& Doi, R. H. (1993a). Conformational properties of the Bacillus subtilis RNA polymerase $\sigma^{\mathrm{A}}$ factor during transcription initiation. Biochem J 294, 43-47.

Chang, B.-Y. \& Doi, R. H. (1993b). Effects of amino acid substitutions in the promoter -10 binding region of the $\sigma^{A}$ factor on growth of Bacillus subtilis. J Bacteriol 175, 2470-2474.

Chang, B.-Y., Chen, K.-Y., Wen, Y.-D. \& Liao, C.-T. (1994). The response of a Bacillus subtilis temperature-sensitive sigA mutant to heat stress. J Bacteriol 176, 3102-3110.

Daniels, D., Zuber, P. \& Losick, R. (1990). Two amino acids in an RNA polymerase $\sigma$ factor involved in the recognition of adjacent base pairs in the -10 region of the cognate promoter. Proc Natl Acad Sci USA 87, 8075-8079.

Davison, B. L., Leighton, T. J. \& Rabinowitz, J. C. (1979). Purification of Bacillus subtilis RNA polymerase with heparin agarose. J Biol Chem 254, 9220-9226.

Davison, B. L., Murray, C. L. \& Rabinowitz, J. C. (1980). Specificity of promoter site utilization in vitro by bacterial RNA polymerase on Bacillus phage $\phi 29$ DNA. Transcription mapping with exonuclease III. J Biol Chem 255, 8819-8830. 
Fukuda, R. \& Doi, R. H. (1977). Two polypeptides associated with the ribonucleic acid polymerase core of Bacillus subtilis during sporulation. J Bacteriol 129, 422-432.

Gardella, T., Moyle, H. \& Susskind, M. M. (1989). A mutant Escherichia coli $\sigma^{70}$ subunit of RNA polymerase with altered promoter specificity. J Mol Biol 206, 579-590.

Grossman, A. D., Burgess, R. R., Walter, W. A. \& Gross, C. A. (1983). Mutations in the lon gene of E. coli K12 phenotypically suppress a mutation in the sigma subunit of RNA polymerase. Cell 32, 151-159.

Halling, S. M., Sanchez-Anzaldo, F. J., Fukuda, R., Doi, R. H. \& Meares, C. F. (1977). Zinc is associated with the $\beta$ subunit of DNA-dependent RNA polymerase of Bacillus subtilis. Biochemistry 16, 2880-2884.

He, X.-S., Shu, T.-S. \& Doi, R. H. (1991). Construction and use of a Bacillus subtilis mutant deficient in multiple protease genes for the expression of eucaryotic genes. Ann NY Acad Sci 646, 60-77.

Helmann, J. D. \& Chamberlin, M. J. (1988). Structure and function of bacterial sigma factor. Annu Rev Biochem 57, 839-872.

Hicks, K. A. \& Grossman, A. D. (1995). Characterization of csh203:: Tn917lac, a mutation in Bacillus subtilis that makes the sporulation sigma factor sigma-H essential for normal vegetative growth. J Bacteriol 177, 3736-3742.

Iglesias, A. \& Trautner, T. A. (1983). Plasmid transformation in Bacillus subtilis: symmetry of gene conversion in transformation of a hybrid plasmid containing chromosomal DNA. Mol Gen Genet 189, 73-76.

Kahn, D. \& Ditta, G. (1991). Modular structure of Fix J: homology of the transcriptional activator domain with the -35 binding domain of sigma factor. Mol Microbiol 5, 987-997.

Kenney, T. J. \& Moran, C. P. (1991). Genetic evidence for interaction of $\sigma^{\mathrm{A}}$ with two promoters in Bacillus subtilis. $J$ Bacteriol 173, 3282-3290.

Kenney, T. J., York, K., Youngman, P. \& Moran, C. P. (1989). Genetic evidence that RNA polymerase associated with $\sigma^{\mathrm{A}}$ uses a sporulation-specific promoter in Bacillus subtilis. Proc Natl Acad Sci USA 86, 9109-9113.

Kiode, Y., Nakamura, A., Uozumi, T. \& Beppu, T. (1986). Cloning and sequencing of the major intracellular serine protease gene of Bacillus subtilis. J Bacteriol 167, 110-116.

Laemmli, U. K. (1970). Cleavage of structural proteins during the assembly of the head of bacteriophage T4. Nature 227, 680-685.

Leighton, T. J. \& Doi, R. H. (1971). The stability of messenger ribonucleic acid during sporulation in Bacillus subtilis. J Biol Chem 246, 3189-3195.

Li, M. \& Wang, S.-L. (1992). Cloning and characterization of the groESL operon from Bacillus subtilis. J Bacteriol 174, 3981-3992.

Liebke, H., Gross, C. A., Walter, W. A. \& Burgess, R. R. (1980). A new mutation, $r p o D 800$, affecting the sigma subunit of $E$. coli RNA polymerase is allelic to two other sigma mutants. Mol Gen Genet 177, 277-282.
Lonetto, M., Gribskov, M. \& Gross, C. A. (1992). The $\sigma^{70}$ family: sequence conservation and evolutionary relationships. J Bacteriol 174, 3843-3849.

Miller, J. H. (1972). Experiments in Molecular Genetics. Cold Spring Harbor, NY: Cold Spring Harbor Laboratory.

Qi, F.-X. (1990). Regulation of the sigA operon and its function during sporulation of Bacillus subtilis. PhD thesis. University of California, Davis.

Qi, F.-X., He, X.-S. \& Doi, R. H. (1991). Localization of a new promoter, $\mathrm{P} 5$, in the sigA operon of Bacillus subtilis and its regulation in some spore mutant strains. J Bacteriol 173, 7050-7054.

Schmidt, A., Schiesswohl, M., Volker, U., Hecker, M. \& Schumann, W. (1992). Cloning, sequencing, mapping, and transcriptional analysis of the groESL operon from Bacillus subtilis. J Bacteriol 174, 3993-3999.

Siegele, D. A., Hu, J.-C., Walter, W. A. \& Gross, C. A. (1989). Altered promoter recognition by mutant forms of the $\sigma^{70}$ subunit of Escherichia coli RNA polymerase. J Mol Biol 206, 591-603.

Spizizen, J. (1958). Transformation of biochemically different strains of Bacillus subtilis by deoxyribonucleate. Proc Natl Acad Sci USA 44, 1072-1078.

Tabor, S. (1990). Expression using the T7 RNA polymerase/ promoter system. In Current Protocols in Molecular Biology, pp. 16.2.1-16.2.11. Edited by F. A. Ausubel, R. Brent, R. E. Kingston, D. D. Moore, J. G. Seidman, J. A. Smith \& K. Struhl. New York: Greene Publishing \& Wiley Interscience.

Tatti, K. M., Jones, C. H. \& Moran, C. P. (1991). Genetic evidence for interaction of $\sigma^{\mathrm{E}}$ with the spoIIID promoter in Bacillus subtilis. J Bacteriol 173, 7828-7833.

Taylor, W. E., Straus, D. B., Grossman, A. D., Burton, Z. F., Gross, C. A. \& Burgess, R. R. (1984). Transcription from a heat-inducible promoter causes heat shock regulation of the sigma subunit of E. coli RNA polymerase. Cell 38, 371-381.

Waldburger, C., Gardella, T., Wong, R. \& Susskind, M. M. (1990). Changes in conserved region 2 of Escherichia coli $\sigma^{70}$ affecting promoter recognition. J Mol Biol 215, 267-276.

Wang, L.-F. \& Doi, R. H. (1986). Nucleotide sequence and organization of Bacillus subtilis RNA polymerase major sigma $\left(\sigma^{43}\right)$ operon. Nucleic Acids Res 14, 4293-4307.

Wang, L.-F. \& Doi, R. H. (1987). Promoter switching during development and termination site of the $\sigma^{43}$ operon of Bacillus subtilis. Mol Gen Genet 207, 114-119.

Yuan, G. \& Wong, S.-L. (1995). Isolation and characterization of Bacillus subtilis groE regulatory mutants: evidence for orf 39 in the $d n a K$ operon as a repressor gene in regulating the expression of both groE and dnaK. J Bacteriol 177, 6462-6468.

Zuber, P., Healy, J., Carter, H. L., Cutting, S., Moran, C. P. \& Losick, R. (1989). Mutation changing the specificity of an RNA polymerase sigma factor. $J \mathrm{Mol}$ Biol 206, 605-614.

Received 27 September 1996; revised 19 November 1996; accepted 2 December 1996. 